\title{
Effects of Monensin and Dietary Soybean Oil on Milk Fat Percentage and Milk Fatty Acid Profile in Lactating Dairy Cows
}

\author{
O. AlZahal, ${ }^{\star}$ N. E. Odongo, ${ }^{\star}$ T. Mutsvangwa, $\dagger$ M. M. Or-Rashid, ${ }^{*}$ T. F. Duffield, ${ }^{*}$ R. Bagg,‡ P. Dick, $\ddagger$ \\ G. Vessie, $\ddagger$ and B. W. McBride ${ }^{\star 1}$ \\ *University of Guelph, Guelph, Ontario, N1G 2W1 Canada \\ †University of Saskatchewan, Saskatoon, Saskatchewan, S7N 5A8 Canada \\ łElanco Animal Health, Division Eli Lilly Canada Inc., Guelph, Ontario, N1G 4T2 Canada
}

\begin{abstract}
The objective of this study was to investigate the effect of monensin (MN) and dietary soybean oil (SBO) on milk fat percentage and milk fatty acid (FA) profile. The study was conducted as a randomized complete block design with a $2 \times 3$ factorial treatment arrangement using 72 lactating multiparous Holstein dairy cows (138 $\pm 24 \mathrm{~d}$ in milk). Treatments were [dry matter (DM) basis] as follows: 1) control total mixed ration (TMR, no MN) with no supplemental SBO; 2) MNtreated TMR (22 $\mathrm{g}$ of MN/kg of DM) with no supplemental SBO; 3) control TMR including 1.7\% SBO; 4) MNtreated TMR including $1.7 \%$ SBO; 5) control TMR including $3.4 \%$ SBO; and 6) MN-treated TMR including $3.4 \%$ SBO. The TMR (\% of DM; corn silage, 31.6\%; haylage, $21.2 \%$; hay, $4.2 \%$; high-moisture corn, $18.8 \%$; soy hulls, 3.3\%; and protein supplement, $20.9 \%$ ) was offered ad libitum. The experiment consisted of a 2wk baseline, a 3 -wk adaptation, and a 2 -wk collection period. Monensin, SBO, and their interaction linearly reduced milk fat percentage. Cows receiving SBO with no added MN (treatments 3 and 5) had 4.5 and $14.2 \%$ decreases in milk fat percentage, respectively. Cows receiving SBO with added MN (treatments 4 and 6) had 16.5 and $35.1 \%$ decreases in milk fat percentage, respectively. However, the interaction effect of $\mathrm{MN}$ and SBO on fat yield was not significant. Monensin reduced milk fat yield by $6.6 \%$. Soybean oil linearly reduced milk fat yield and protein percentage and linearly increased milk yield and milk protein yield. Monensin and SBO reduced $4 \%$ fat-corrected milk and had no effect on DM intake. Monensin interacted with SBO to linearly increase milk fat concentration ( $\mathrm{g} / 100 \mathrm{~g}$ of FA) of total trans-18:1 in milk fat including trans-6 to 8, trans-9, trans-10, trans-11, trans-12 18:1 and the concentration of total conjugated linoleic acid isomers including cis-
\end{abstract}

Received March 26, 2007.

Accepted November 23, 2007.

${ }^{1}$ Corresponding author: bmcbride@uoguelph.ca
9, trans-11 18:2; trans-9, cis-11 18:2; and trans-10, cis-12 18:2. Also, the interaction increased milk concentration of polyunsaturated fatty acids. Monensin and SBO linearly reduced, with no significant interaction, milk concentration ( $\mathrm{g} / 100 \mathrm{~g}$ of FA) of short- and medium-chain fatty acids $(<\mathrm{C} 16)$. Soybean oil reduced total saturated FA and increased total monounsaturated FA. These results suggest that monensin reduces milk fat percentage and this effect is accentuated when SBO is added to the ration.

Key words: dairy cow, monensin, soybean oil, milk fat percentage

\section{INTRODUCTION}

Monensin (MN) is a carboxylic polyether ionophore antibiotic produced by fermentation of Streptomyces cinnamonensis (Russell, 2002). The benefits of feeding MN to dairy cattle in early lactation include increased milk production and improved energy balance associated with reduced incidence of subclinical ketosis, clinical acidosis, and displaced abomasums (Duffield and Bagg, 2000). Various studies have reported depressed milk fat percentage with MN (Phipps et al., 2000; Odongo et al., 2007a), whereas others (Lean et al., 1994; Duffield et al., 1999) reported no effect. The source of inconsistency of the fat-depressing effect of $\mathrm{MN}$ in the literature may be due to interaction with dietary factors such as MN dose level (Symanowski et al., 1999), method of administration of MN, stage of lactation (Duffield and Bagg, 2000), and feeding system (TMR vs. component-fed; Duffield et al., 2003).

Feeding unsaturated oil impaired ruminal biohydrogenation (BH) of unsaturated fatty acids (FA; Bauman and Griinari, 2001, 2003) and increased ruminal outflow of $\mathrm{BH}$ intermediates that were considered potent inhibitors of milk fat synthesis such as trans-10, cis-12 conjugated linoleic fatty acid (CLA; Baumgard et al., 2000), cis-10, trans-12 CLA (Sæbø et al., 2005), and trans-9, cis-11 CLA (Perfield et al., 2007). Similar to unsaturated oil, ionophores inhibited ruminal BH (Jen- 
kins et al., 2003). Fellner et al. (1997) successfully maintained high concentrations of linoleic acid, trans 18:1, and CLA in continuous cultures of ruminal bacteria when different ionophores such as $\mathrm{MN}$, nigercin, and tetronasin were added. Furthermore, Jenkins et al. (2003) found that combining MN with soybean oil (SBO) increased the level of trans 18:1 in bacterial culture, especially trans-10 18:1.

The objective of this study was to investigate the effect of MN and dietary SBO on milk fat percentage and milk FA profile in lactating Holstein cows during mid lactation.

\section{MATERIALS AND METHODS}

\section{Animals and Experimental Design}

Seventy-two lactating Holstein dairy cows $(1.8 \pm 1.3$ parity, $138 \pm 24$ DIM) housed in a tie-stall facility at the Elora Dairy Research Centre, University of Guelph (Guelph, Ontario, Canada) were used in this study. Two animals were removed from the experiment due to health problems. Animals were cared for and handled in accordance with the Canadian Council on Animal Care regulations. The University of Guelph Animal Care Committee approved their use for this experiment. The study was conducted as a $2 \times 3$ factorial arrangement with 2 levels of MN ( 0 or $22 \mathrm{mg} / \mathrm{kg}$ of $\mathrm{DM}$ ) and 3 levels of supplemental SBO (0, 1.7, and $3.4 \%$ of DM). The experiment was conducted using 12 cows at a given time ( 6 blocks). Within each block the cows were randomly assigned to 1 of the 6 treatments. Each block consisted of a 2 -wk baseline period, a 3 -wk adaptation period, and a 2 -wk collection period.

\section{Experimental Measures and Samples Analyses}

Diets were formulated according to the NRC (2001) guidelines to meet the requirement for a dairy cow $(\mathrm{BW}=680 \mathrm{~kg})$ during mid lactation $(\mathrm{DIM}=90)$ and producing $35 \mathrm{~kg} / \mathrm{d}$ milk, $4.0 \%$ milk fat, and $3.5 \%$ true protein. The diet was fed as a TMR twice daily at 0700 and $1500 \mathrm{~h}$ and water was offered at all times. The offered amount of TMR was adjusted weekly for each individual animal based on the average feed intake from the previous week to maintain approximately 5 $\mathrm{kg}$ of orts.

Ingredients, chemical composition, and the FA profile of experimental TMR and protein supplements are presented in Tables 1, 2, and 3, respectively.

During adaptation and collection periods, animals were fed 1 of 3 TMR [low (L), moderate (M), or high (H)] with either no monensin (control) or with supplemental MN (DM basis, 22 g/kg Rumensin Premix, Elanco Animal Health, Division Eli Lilly Canada Inc., Guelph,
Table 1. Ingredients and chemical composition of low, medium, and high polyunsaturated fatty acid TMR

\begin{tabular}{|c|c|c|c|}
\hline Ingredient & & $\%$ of $\mathrm{DM}$ & \\
\hline Corn silage & & 31.6 & \\
\hline Mixed haylage & & 21.2 & \\
\hline High-moisture corn & & 18.8 & \\
\hline Mixed hay & & 4.2 & \\
\hline Soybean hulls & & 3.3 & \\
\hline Protein supplement ${ }^{1}$ & & 20.9 & \\
\hline Chemical composition & Low & Medium & High \\
\hline DM, \% & 50.5 & 50.5 & 50.7 \\
\hline $\mathrm{CP}$ & 17.6 & 17.7 & 17.7 \\
\hline Soluble protein, \% of CP & 37.0 & 38.0 & 37.1 \\
\hline RUP, \% of CP & 31.5 & 31.0 & 31.4 \\
\hline $\mathrm{ADP}, \%$ of $\mathrm{CP}$ & 7.6 & 7.7 & 8.0 \\
\hline $\mathrm{NDP}, \%$ of $\mathrm{CP}$ & 25.7 & 26.7 & 27.5 \\
\hline $\mathrm{ADF}$ & 23.2 & 22.6 & 22.4 \\
\hline NDF & 36.2 & 35.5 & 34.8 \\
\hline Lignin, \% of NDF & 8.8 & 9.2 & 11.5 \\
\hline $\mathrm{Ca}$ & 1.1 & 1.0 & 1.0 \\
\hline $\mathrm{P}$ & 0.5 & 0.5 & 0.5 \\
\hline $\mathrm{K}$ & 1.4 & 1.4 & 1.5 \\
\hline $\mathrm{Mg}$ & 0.3 & 0.3 & 0.3 \\
\hline $\mathrm{Na}$ & 0.5 & 0.5 & 0.4 \\
\hline $\mathrm{NE}_{\mathrm{L}}{ }^{2} \mathrm{Mcal} / \mathrm{kg}$ & 1.5 & 1.5 & 1.5 \\
\hline $\mathrm{NFC}^{3}$ & 39.1 & 39.3 & 39.8 \\
\hline Crude fat & 3.3 & 4.4 & 4.9 \\
\hline Ash & 8.0 & 7.8 & 7.8 \\
\hline
\end{tabular}

${ }^{1}$ Ingredients and chemical composition of supplements are presented in Table 2.

${ }^{2}$ Estimated using equations and values according to NRC (2001).

${ }^{3} \mathrm{NFC}=100-[\mathrm{NDF}+(\mathrm{CP}-$ neutral detergent insoluble protein $)$ + ether extract + ash $]$.

Ontario, Canada). The L, M, and H TMR included (\% of DM) $0,1.7$, or $3.4 \%$ supplemental $\mathrm{SBO}$, respectively. The SBO was added to the protein supplement where applicable. The MN premix was incorporated into soybean hulls, which acted as the carrier, and mixed with the TMR. The control TMR was mixed with a placebo premix consisting of only soybean hulls without MN. Cows were offered the experimental diets for $3 \mathrm{wk}(\mathrm{ad}-$ aptation period) to allow the ruminal microflora to adjust to the supplemental MN and SBO. Therefore, during the collection period, the cows were assumed to have reached a steady state. During the baseline period, animals were fed the L TMR with no supplemental MN.

Feed intake and milk yield were monitored daily throughout the experiment. Feed samples and individual cow orts samples were collected 3 times per week and frozen at $-20^{\circ} \mathrm{C}$ for analysis. Feed samples were pooled by treatment each week, whereas orts samples were pooled weekly by cow in proportion to the amount of orts. Pooled feed and ort samples were dried at $100^{\circ} \mathrm{C}$ for $48 \mathrm{~h}$ in a forced-air oven to determine the DM content. Dried samples were ground (1-mm screen; Wiley mill, Arthur H. Thomas Co., Philadelphia, PA) and 
Table 2. Ingredients and chemical composition of low, moderate, and high polyunsaturated fatty acid supplements

\begin{tabular}{|c|c|c|c|}
\hline \multirow[b]{2}{*}{ Ingredient } & \multicolumn{3}{|c|}{ Supplement, \% of DM } \\
\hline & Low & Medium & High \\
\hline Soyhulls & 13.6 & 4.4 & 0.6 \\
\hline Soybean meal $48 \%$ & 20.5 & 21.2 & 26.9 \\
\hline Canola meal & 10.1 & 9.6 & 3.3 \\
\hline Corn gluten meal & 16.3 & 17.3 & 18.9 \\
\hline Roasted whole soybeans & 10.0 & 10.2 & 9.5 \\
\hline Beet pulp & 4.1 & 4.1 & 1.4 \\
\hline Blood meal & 2.5 & 2.5 & 2.5 \\
\hline Herring fish meal & 3.7 & 3.8 & 3.4 \\
\hline Golden flake & 2.0 & 2.0 & 2.0 \\
\hline Molasses & 1.6 & 1.6 & 0.8 \\
\hline Soybean oil & 0.0 & 8.1 & 16.3 \\
\hline Salt & 2.5 & 2.5 & 2.5 \\
\hline Calcium carbonate & 4.3 & 4.4 & 4.6 \\
\hline Dicalcium phosphate & 3.3 & 3.3 & 3.5 \\
\hline Sodium bicarbonate & 3.3 & 3.4 & 3.4 \\
\hline Micro premix ${ }^{1}$ & 0.63 & 0.63 & 0.63 \\
\hline Magnesium oxide & 0.60 & 0.60 & 0.68 \\
\hline Sulfur flour (99.5) & 0.30 & 0.30 & 0.33 \\
\hline Other ingredients ${ }^{2}$ & 0.55 & 0.76 & 0.87 \\
\hline \multicolumn{4}{|l|}{ Chemical composition } \\
\hline DM, \% & 91.4 & 91.9 & 92.6 \\
\hline $\mathrm{CP}$ & 37.5 & 38.1 & 38.1 \\
\hline Soluble protein, $\%$ of $\mathrm{CP}$ & 6.3 & 11.4 & 7.1 \\
\hline RUP, \% of CP & 46.8 & 44.3 & 46.5 \\
\hline $\mathrm{ADF}$ & 13.4 & 10.5 & 9.9 \\
\hline $\mathrm{NDF}$ & 20.2 & 17.0 & 13.6 \\
\hline Lignin, \% of NDF & 10.0 & 12.0 & 23.0 \\
\hline $\mathrm{Ca}$ & 2.83 & 2.63 & 2.68 \\
\hline $\mathrm{P}$ & 1.22 & 1.20 & 1.21 \\
\hline $\mathrm{K}$ & 1.23 & 1.19 & 1.26 \\
\hline $\mathrm{Mg}$ & 0.55 & 0.55 & 0.55 \\
\hline $\mathrm{Na}$ & 2.00 & 2.01 & 1.90 \\
\hline $\mathrm{NE}_{\mathrm{L}},{ }^{3} \mathrm{Mcal} / \mathrm{kg}$ & 1.68 & 1.73 & 1.74 \\
\hline $\mathrm{NFC}^{4}$ & 27.3 & 28.0 & 30.3 \\
\hline Crude fat & 5.4 & 10.3 & 12.7 \\
\hline Ash & 17.6 & 16.4 & 16.6 \\
\hline
\end{tabular}

${ }^{1}$ Contained (DM basis): $0.70 \% \mathrm{~S}, 1.56 \% \mathrm{Cl}, 660 \mathrm{mg}$ of $\mathrm{Fe} / \mathrm{kg}, 496$ $\mathrm{mg}$ of $\mathrm{Zn} / \mathrm{kg}, 116.05 \mathrm{mg}$ of $\mathrm{Cu} / \mathrm{kg}, 495 \mathrm{mg}$ of $\mathrm{Mn} / \mathrm{kg}, 1.16 \mathrm{mg}$ of Se/ $\mathrm{kg}, 8.4 \mathrm{mg}$ of Co/kg, $5.72 \mathrm{mg}$ of I/kg, 48,290 IU of vitamin A/kg, 12,080 IU of vitamin $\mathrm{D} / \mathrm{kg}$, and $179 \mathrm{IU}$ vitamin $\mathrm{E} / \mathrm{kg}$.

${ }^{2}$ Other ingredients included Fibrozyme (Alltech Inc., Lexington, KY), Yea-Sacc 1026 (Alltech Inc.), potassium chloride, and Rovimix H2 (DSM, Ayr, Ontario, Canada).

${ }^{3}$ Estimated using equations and values according to NRC (2001).

${ }^{4} \mathrm{NFC}=100-[\mathrm{NDF}+(\mathrm{CP}-$ neutral detergent insoluble protein $)$ + ether extract + ash $]$.

pooled by period. Representative samples of each supplement were taken from each batch during the adaptation and collection periods and pooled for analysis. Samples were analyzed at Agri-Food Laboratory, Guelph (Ontario, Canada) for DM, CP, Ca, P, Mg, K, Na, ash, ether extract, lignin, ADF (AOAC, 1996), and NDF (Mertens, 2002). Soluble CP, NDF-CP, and neutral detergent insoluble protein were determined by methods described by Licitra et al. (1996).
Table 3. Fatty acid profile ( $\mathrm{g} / 100 \mathrm{~g}$ of total fatty acids) of low, moderate, and high soybean oil TMR

\begin{tabular}{lccc}
\hline & \multicolumn{3}{c}{ TMR } \\
\cline { 2 - 4 } Item & Low & Moderate & High \\
\hline $10: 0$ & 0.051 & 0.047 & 0.045 \\
$12: 0$ & 0.22 & 0.19 & 0.18 \\
$14: 0$ & 0.53 & 0.49 & 0.46 \\
$15: 0$ & 0.106 & 0.099 & 0.097 \\
$16: 0$ & 15.2 & 14.9 & 14.8 \\
$16: 1$ cis-9 & 0.42 & 0.38 & 0.34 \\
$17: 0$ & 0.31 & 0.30 & 0.30 \\
$17: 0$ anteiso & 0.147 & 0.148 & 0.146 \\
$18: 0$ & 3.17 & 3.10 & 2.96 \\
$18: 1$ cis-9 & 0.34 & 0.29 & 0.26 \\
$18: 1$ cis-11 & 20.2 & 20.3 & 20.1 \\
$18: 1$ cis-12 & 2.1 & 2.0 & 2.0 \\
$18: 1$ cis-13 & 0.434 & 0.467 & 0.467 \\
$18: 1$ cis-14/trans- 16 & 0.055 & 0.057 & 0.059 \\
$18: 1$ trans & 0.527 & 0.527 & 0.527 \\
$18: 2 \mathrm{n}-6$ & 42.8 & 43.4 & 44.0 \\
$18: 3 \mathrm{n}-3$ & 11.9 & 12.0 & 12.1 \\
$20: 0$ & 0.400 & 0.398 & 0.395 \\
$20: 1$ cis-11 & 0.030 & 0.027 & 0.026 \\
$20: 2 \mathrm{n}-6$ & 0.31 & 0.23 & 0.18 \\
$20: 4 \mathrm{n}-6$ & 0.064 & 0.061 & 0.058 \\
$20: 5 \mathrm{n}-3$ & 0.08 & 0.04 & 0.02 \\
$22: 0$ & 0.268 & 0.266 & 0.268 \\
$22: 1$ cis-13 & 0.04 & 0.02 & 0.01 \\
$22: 6 \mathrm{n}-3$ & 0.09 & 0.04 & 0.03 \\
$23: 0$ & 0.042 & 0.043 & 0.043 \\
$24: 0$ & 0.170 & 0.168 & 0.165 \\
\hline & & &
\end{tabular}

Cows were milked twice daily at 0500 and $1500 \mathrm{~h}$, and milk weights were recorded. Milk samples were collected in duplicate 3 times per week during wk 1 and 2 (baseline) and wk 6 and 7 (treatment) from a.m. and p.m. milkings. Samples for milk components analysis were preserved with 2-bromo-2-nitropropane-1-2-diol and stored at $4^{\circ} \mathrm{C}$ until analysis. Milk samples were pooled daily based on a constant proportion of 60:40 (a.m.:p.m.) and then weekly using equal proportions and submitted to the DHI testing laboratory (Ontario Dairy Herd Improvement Corp., Guelph, Ontario, Canada) for analysis. Milk samples were analyzed for milk protein, fat, and lactose using a near-infrared analyzer (Foss System 4000, Foss Electric, Hillerød, Denmark). Milk samples for FA analysis were frozen immediately at $-20^{\circ} \mathrm{C}$ until analysis.

\section{Milk FA Analysis}

Frozen milk samples were thawed at $37^{\circ} \mathrm{C}$ and pooled per cow daily as explained above and then pooled by period; that is, baseline $(\mathrm{n}=70)$ and treatment $(\mathrm{n}=$ 70). Lipids for FA analysis were extracted from pooled milk samples according to Bligh and Dyer (1959) and as modified by Odongo et al. (2007b).

Fatty acids methyl ester (FAME) analysis was performed using an Agilent 6890N GLC (Agilent Techno- 
logies, Palo Alto, CA) equipped with a split/splitless injector at $250^{\circ} \mathrm{C}$, a flame-ionization detector at $250^{\circ} \mathrm{C}$ (Agilent Technologies), and a CP Sil 88 column (100 m, $0.25 \mathrm{~mm}, 0.2-\mu \mathrm{m}$ film thickness, Varian, Mississauga, Ontario, Canada). Agilent Chemstation software (Rev. B.01.01) was used for data analysis. Hydrogen was used as carrier gas at a constant flow rate of $1 \mathrm{~mL} / \mathrm{min}$. The temperature of the GLC oven was set to $45^{\circ} \mathrm{C}$ for 4 min, increased at $13^{\circ} \mathrm{C} / \mathrm{min}$ to $175^{\circ} \mathrm{C}$, held for $27 \mathrm{~min}$, increased at $4^{\circ} \mathrm{C} / \mathrm{min}$ to a final temperature of $215^{\circ} \mathrm{C}$, and held for $35 \mathrm{~min}$. A $1-\mu \mathrm{L}$ sample containing 1 to 2 $\mu \mathrm{g}$ was injected at splitless mode to determine FAME presence at low concentration. Peaks were identified by comparison of retention times with a GLC reference FAME standard (GLC \#463, \#UC-59-M, 21:0, 23:0, and 26:0; Nu-Chek Prep Inc., Elysian, MN). The trans-11, cis-15 18:2 was identified by cross-referencing with previously published isomeric profiles reported for milk fat using cis-9, cis-12 18:2 as a landmark isomer (Ulberth and Henninger, 1994; Precht and Molkentin, 1997). Individual isomers of 18:1 FA were determined as follows: The temperature of the GLC oven was maintained at $45^{\circ} \mathrm{C}$ for $4 \mathrm{~min}$, increased to $167^{\circ} \mathrm{C}$ at a rate of $13^{\circ} \mathrm{C} /$ min and held for $40 \mathrm{~min}$, and again increased at the rate of $4^{\circ} \mathrm{C} / \mathrm{min}$ to a final temperature of $218^{\circ} \mathrm{C}$ and held for $23 \mathrm{~min}$. Separation of trans and cis octadecenoic acids was incomplete, but the chromatography allowed the major isomers of interest to be resolved. The trans6, trans-7, and trans-8 18:1 isomers and the trans-13 and trans-14 18:1 isomers remained unresolved as single peaks. Individual trans isomers were identified by cross-referencing with previously published isomeric profiles reported for milk fat (Precht and Molkentin, 1997; Shingfield et al., 2003; Loor et al., 2004) using trans-11 18:1 as a landmark isomer. Fatty acid composition was expressed in grams per one hundred grams of total FA. Feed FA analysis was conducted on dried, ground, and pooled samples of L, M, and H TMR as mentioned above.

\section{Statistical Analysis}

Dry matter intake, milk yield, and milk component averages for the collection period and milk FA concentrations of composite samples were analyzed using Proc Mixed (SAS Institute, 2004) using the model

$$
\mathrm{Y}_{\mathrm{ijk}}=\mu+\mathrm{M}_{\mathrm{i}}+\mathrm{S}_{\mathrm{j}}+(\mathrm{M} \times \mathrm{S})_{\mathrm{ij}}+\mathrm{B}_{\mathrm{k}}+\mathrm{e}_{\mathrm{ijk}}
$$

where $Y_{i j k}=$ the dependent variable, $\mu$ = overall mean, $\mathrm{M}_{\mathrm{i}}=$ effect of monensin ( $\left.\mathrm{i}=1,2\right), \mathrm{S}_{\mathrm{j}}=$ effect of soybean oil $(\mathrm{j}=1,2,3),(\mathrm{M} \times \mathrm{S})_{\mathrm{ij}}=$ effect of monensin $\times$ soybean oil (ij $=1,2,3,4,5,6), \mathrm{B}_{\mathrm{k}}=$ effect of block $(\mathrm{k}=1,2,3,4$, $5,6)$, and $\mathrm{e}_{\mathrm{ijk}}=$ random residual error.
The model included the average of the baseline period as a covariate and the effects of MN, SBO, and block were considered as fixed effects. Orthogonal polynomial contrasts were used to describe the linear and quadratic terms of SBO effect and their interactions with MN.

\section{RESULTS}

\section{Intake, Milk Yield, and Milk Components}

Dry matter intake, milk yield, milk fat percentage, milk fat yield, milk protein percentage, and milk protein yield are presented in Table 4 . Monensin had no effect on DMI, milk yield ( $\mathrm{kg} / \mathrm{d})$, milk protein percentage, or milk protein yield $(\mathrm{kg} / \mathrm{d})$, and reduced milk fat percentage, fat yield, and 4\% FCM (Table 4).

Soybean oil supplementation had no effect on DMI, linearly increased $(P<0.05)$ milk yield and milk protein yield, and linearly reduced $(P<0.05)$ milk protein percentage, milk fat percentage, and 4\% FCM (Table 4). Soybean oil supplementation interacted with MN to linearly further reduce milk fat percentage. Cows receiving the $\mathrm{H}$ TMR with MN had the lowest milk fat percentage (2.43\%) compared with cows receiving $\mathrm{H}$ TMR without MN (3.14\%).

\section{Milk FA Composition}

The effect of MN and SBO on milk fat concentration ( $\mathrm{g} / 100 \mathrm{~g}$ of FA) during the treatment period is presented in Tables 5, 6, and 7.

Monensin, SBO, and their interaction increased cis9 14:1 (Table 5); trans-6 to 8; trans-9; trans-10; trans11; trans-12 18:1 (Table 7); total trans 18:1 (Table 5); cis-9, trans-11 CLA, trans-9, cis-11 CLA, trans-10, cis12 CLA; and total CLA (Table 6).

Monensin reduced $(P<0.05) 6: 0,8: 0,10: 0,14: 0$ iso, 15:0 iso, 15:0 anteiso, 16:0 iso, 18:0, 18:3n-3, 18:3n-6, 20:0, 20:2n-6, 20:3n-6, 20:4n-3, 20:4n-6, 20:5n-3, 22:0, 22:4n-6, 22:5n-3, and 22:6n-3 FA. Monensin reduced total de novo FA $(<\mathrm{C} 16)$. Monensin numerically $(P<$ $0.10)$ reduced total saturated FA by $2 \%$ and increased numerically total monounsaturated FA (MUFA) by $5 \%$ (Table 5). Monensin increased $(P<0.05)$ cis-9 16:1 (Table 5).

Soybean oil had a significant linear effect on most FA analyzed in this study (Tables 5, 6, and 7). Soybean oil reduced total de novo FA $(<\mathrm{C} 16)$, total 16:0 + 16:1, and total saturates (Table 5). On the other hand, SBO increased total preformed FA (>C16) and total MUFA.

Soybean oil interacted with MN (main effect of MN was not significant) to increase trans-4 18:1; 18:2n-6 (linoleic acid); trans-11, cis-15 18:2; cis-11 20:1; and total polyunsaturated FA (Tables 6 and 7). 
Table 4. Mean effects of 3 levels of soybean oil (SBO; 0, 1.7, or 3.4\% of DM) and monensin (MN; 0 vs. 22 $\mathrm{g} / \mathrm{kg}$ of DM) in the diet on DMI, milk yield, milk fat percentage, milk fat yield, milk protein percentage, and milk protein yield in lactating dairy cows

\begin{tabular}{|c|c|c|c|c|c|c|c|c|c|c|}
\hline \multirow[b]{2}{*}{ Item } & \multicolumn{3}{|c|}{ Control (no MN) } & \multicolumn{3}{|c|}{$\mathrm{MN}(22 \mathrm{~g} / \mathrm{kg}$ of $\mathrm{DM})$} & \multirow[b]{2}{*}{ SEM } & \multicolumn{3}{|c|}{$P$-value ${ }^{1}$} \\
\hline & 0 & 1.7 & 3.4 & 0 & 1.7 & 3.4 & & $\mathrm{MN}$ & SBO & $\mathrm{MN} \times \mathrm{SBO}$ \\
\hline DMI, kg/d & 21.3 & 20.7 & 20.9 & 20.6 & 21.0 & 21.5 & 0.50 & NS & NS & NS \\
\hline Milk yield, kg/d & 27.5 & 29.5 & 29.4 & 26.9 & 28.9 & 30.1 & 0.75 & NS & $* *$ & NS \\
\hline Milk fat, $\%$ & 3.76 & 3.59 & 3.14 & 3.74 & 3.21 & 2.43 & 0.15 & $* *$ & $* * *$ & $*$ \\
\hline Milk fat, $\mathrm{kg} / \mathrm{d}$ & 1.03 & 1.05 & 0.92 & 0.99 & 0.92 & 0.74 & 0.04 & $* *$ & $* * *$ & NS \\
\hline Milk protein, \% & 3.35 & 3.26 & 3.27 & 3.31 & 3.24 & 3.23 & 0.04 & NS & * & NS \\
\hline Milk protein, $\mathrm{kg} / \mathrm{d}$ & 0.93 & 0.96 & 0.95 & 0.88 & 0.93 & 0.97 & 0.02 & NS & $*$ & NS \\
\hline $4 \%$ FCM, kg/d & 26.4 & 27.6 & 25.5 & 25.6 & 25.2 & 23.1 & 0.65 & $* *$ & $*$ & NS \\
\hline
\end{tabular}

${ }^{1}$ Probability of significant effects of $\mathrm{MN}$, SBO (linear), and their interaction (MN $\times \mathrm{SBO}$, linear); $* P<$ $0.05 ; * * P<0.01 ; * * * P<0.001$.

\section{DISCUSSION}

The potential of MN to improve the performance of lactating dairy cows has received considerable attention over the last few years. In several studies, MN has been shown to reduce DMI in dairy cows (Johnson et al., 1988; Sauer et al., 1989; Green et al., 1999) and increase milk production (Hayes et al., 1996; van der Werf et al., 1998; Duffield et al., 1999). In the current study, MN had no effect on DMI and milk yield (Table 4) in agreement with Dye et al. (1988), Ramanzin et al. (1997), and Phipps et al. (2000). Monensin also had no effect on milk protein percentage or milk protein yield, in agreement with several previous studies (van der Werf et al., 1998; Duffield et al., 1999) although other studies have reported a reduction in milk protein percentage with MN (Hayes et al., 1996; Green et al., 1999; Phipps et al., 2000).

Feeding unsaturated oil often caused depressed DMI and milk production (Lock and Shingfield, 2004) because of impaired rumen function (Jenkins, 1993). In the current study, SBO had no effect on DMI and significantly increased milk yield (Table 4 ). The increase in milk production could be related to an increased energy intake with greater SBO level. Soybean oil reduced milk protein percentage and increased $(P<0.05)$ milk protein yield (Table 4). Reduction in milk protein percentage was almost always associated with an increase in milk yield; therefore, it is suggested that milk protein reduction is often caused by a dilution effect rather than a reduction in protein synthesis (DePeters and Cant, 1992; Ipharraguerre and Clark, 2003).

Soybean oil, MN, and their interaction reduced milk fat percentage. Milk fat percentage dropped by 4.5 and $14.2 \%$ when $1.7 \%$ SBO was supplemented and by 16.5 and $35.1 \%$ when $3.4 \%$ of SBO was supplemented, no MN vs. MN, respectively, suggesting that the depression of milk fat percentage was dependent on the level of fat in the diet. The depression in milk fat percentage caused by SBO is in agreement with previous studies that used a combination of extruded soybeans and fish oil (Whitlock et al., 2002; AbuGhazaleh et al., 2004).

In the current study, milk fat depression was associated with a significant increase in total trans 18:1 including trans-10 18:1 (Table 5) and total CLA including cis-9, trans-11 CLA, trans-9, cis-11 CLA, trans-10, cis12 CLA (Table 6).

Trans-10, cis-12 CLA (Baumgard et al., 2000) is considered a potent inhibitor of milk fat synthesis (Bauman and Griinari, 2001, 2003), and the relationship between this CLA isomer and milk fat depression is well established (de Veth et al., 2004; Shingfield et al., 2006). In the current study, trans-10, cis-12 CLA had a strong relationship with milk fat percentage [milk fat percentage $(\mathrm{g} / \mathrm{kg})=20.09 \pm 3.09+25.01 \pm 2.87 \exp (-59.53 \pm$ 22.25 trans -10 , cis -12 CLA), $\left.\mathrm{n}=70, \mathrm{R}^{2}=0.53, P<0.001\right]$.

However, in several diet-induced milk fat depressions, changes in trans-10, cis-12 CLA were not adequate to completely explain the reduction in milk fat, suggesting that additional $\mathrm{BH}$ intermediates might be involved in the regulation of milk fat synthesis (Bauman and Griinari, 2001). Recent studies demonstrated that cis-10, trans-12 CLA (Sæbø et al., 2005) and trans9, cis-11 CLA (Perfield et al., 2007) are also potent inhibitors of milk fat synthesis in dairy cows. The current study showed, however, a weak relationship between milk fat percentage and trans-9, cis-11 CLA $\left(\mathrm{R}^{2}=\right.$ 0.28). Other CLA such as trans-10, trans-12 CLA (Perfield et al., 2006) and trans-9, trans-11 CLA (Perfield et al., 2007) had no effect on milk fat depression, but caused a shift in $\Delta^{9}$-desaturation indices.

Impaired ruminal BH yields many trans 18:1 intermediates, mainly trans-10 18:1. The relationship between this isomer in milk fat and milk fat depression has been well established (Bauman and Griinari, 2003). Recently, Lock et al. (2007) investigated the direct role of trans-10 18:1 on milk fat synthesis. They used 3 midlactating cows in a $3 \times 3$ Latin square design. Cows 
Table 5. Mean effects of 3 levels of soybean oil (SBO; 0, 1.7, or 3.4\% of DM) and monensin (MN, 0 vs. 22 $\mathrm{g} / \mathrm{kg} \mathrm{DM}$ ) in the diet on milk fatty acid (FA) concentrations ( $\mathrm{g} / 100 \mathrm{~g}$ of FA)

\begin{tabular}{|c|c|c|c|c|c|c|c|c|c|c|}
\hline \multirow[b]{2}{*}{ FA } & \multicolumn{3}{|c|}{ Control (no MN) } & \multicolumn{3}{|c|}{$\mathrm{MN}(22 \mathrm{~g} / \mathrm{kg}$ of DM) } & \multirow[b]{2}{*}{ SEM } & \multicolumn{3}{|c|}{$P$-value ${ }^{1}$} \\
\hline & 0 & 1.7 & 3.4 & 0 & 1.7 & 3.4 & & $\mathrm{MN}$ & SBO & $\mathrm{MN} \times \mathrm{SBO}$ \\
\hline $6: 0$ & 1.82 & 1.62 & 1.24 & 1.74 & 1.35 & 0.97 & 0.105 & * & $* * *$ & NS \\
\hline $8: 0$ & 1.21 & 1.06 & 0.78 & 1.07 & 0.86 & 0.59 & 0.068 & $* *$ & $* * *$ & NS \\
\hline $10: 0$ & 2.99 & 2.50 & 1.82 & 2.70 & 2.18 & 1.48 & 0.158 & $*$ & $* * *$ & NS \\
\hline $11: 0$ & 0.35 & 0.28 & 0.21 & 0.30 & 0.28 & 0.18 & 0.026 & NS & $* * *$ & NS \\
\hline $12: 0$ & 3.90 & 3.24 & 2.50 & 3.59 & 3.06 & 2.25 & 0.160 & NS & $* * *$ & NS \\
\hline $14: 0$ & 13.23 & 12.28 & 10.86 & 12.72 & 12.09 & 10.52 & 0.306 & NS & $* * *$ & NS \\
\hline $14: 0$ iso & 0.16 & 0.13 & 0.12 & 0.11 & 0.10 & 0.08 & 0.010 & $* * *$ & $* *$ & NS \\
\hline $14: 1 \mathrm{cis}-9$ & 0.98 & 0.98 & 0.99 & 0.97 & 1.22 & 1.27 & 0.071 & $*$ & * & $*$ \\
\hline $15: 0$ & 1.38 & 1.27 & 1.16 & 1.47 & 1.23 & 1.16 & 0.040 & NS & $* * *$ & NS \\
\hline 15:0 iso & 0.27 & 0.24 & 0.19 & 0.23 & 0.20 & 0.17 & 0.012 & $* *$ & $* * *$ & NS \\
\hline 15:0 anteiso & 0.54 & 0.48 & 0.43 & 0.51 & 0.45 & 0.40 & 0.012 & $* *$ & $* * *$ & NS \\
\hline $16: 0$ & 35.00 & 33.31 & 30.94 & 37.57 & 33.13 & 31.19 & 0.683 & NS & $* * *$ & NS \\
\hline 16:0 iso & 0.40 & 0.37 & 0.33 & 0.31 & 0.30 & 0.27 & 0.019 & $* * *$ & $* *$ & NS \\
\hline $16: 1$ cis -9 & 1.36 & 1.34 & 1.51 & 1.49 & 1.57 & 1.95 & 0.122 & $* *$ & $*$ & NS \\
\hline $17: 0$ & 0.55 & 0.50 & 0.48 & 0.58 & 0.50 & 0.47 & 0.015 & NS & $* * *$ & NS \\
\hline 17:0 anteiso & 0.69 & 0.66 & 0.63 & 0.69 & 0.65 & 0.62 & 0.018 & NS & $* * *$ & NS \\
\hline 18:0 & 10.38 & 11.05 & 11.45 & 9.87 & 10.40 & 9.84 & 0.404 & $* *$ & NS & NS \\
\hline $18: 1 \mathrm{cis}$ & 18.36 & 20.12 & 23.02 & 17.69 & 21.27 & 22.45 & 0.678 & NS & $* * *$ & NS \\
\hline $18: 1$ trans & 2.90 & 4.32 & 6.41 & 2.81 & 4.64 & 8.73 & 0.348 & $* *$ & $* * *$ & $* *$ \\
\hline $18: 1$ total & 21.08 & 24.44 & 29.46 & 20.47 & 26.04 & 31.20 & 0.884 & NS & $* * *$ & NS \\
\hline $18: 2^{2}$ & 2.02 & 2.40 & 2.57 & 1.87 & 2.33 & 2.84 & 0.080 & NS & $* * *$ & $*$ \\
\hline $\mathrm{CLA}^{3}$ & 0.49 & 0.75 & 1.09 & 0.48 & 0.87 & 1.47 & 0.073 & $* *$ & $* * *$ & $*$ \\
\hline $18: 3 n-3$ & 0.38 & 0.42 & 0.40 & 0.35 & 0.37 & 0.41 & 0.013 & * & $* *$ & NS \\
\hline $18: 3 n-6$ & 0.028 & 0.022 & 0.017 & 0.024 & 0.021 & 0.013 & 0.002 & $*$ & $* * *$ & NS \\
\hline 19:0 & 0.071 & 0.077 & 0.082 & 0.075 & 0.074 & 0.088 & 0.004 & NS & $* *$ & NS \\
\hline $20: 0$ & 0.165 & 0.158 & 0.146 & 0.152 & 0.140 & 0.117 & 0.007 & $* *$ & $* * *$ & NS \\
\hline $20: 1$ cis -11 & 0.073 & 0.069 & 0.074 & 0.069 & 0.071 & 0.088 & 0.004 & NS & * & $*$ \\
\hline $20: 2 n-3$ & 0.006 & 0.007 & 0.009 & 0.006 & 0.009 & 0.008 & 0.001 & NS & * & NS \\
\hline $20: 2 n-6$ & 0.024 & 0.023 & 0.021 & 0.022 & 0.021 & 0.017 & 0.001 & $* *$ & $* *$ & NS \\
\hline $20: 3 n-3$ & 0.006 & 0.005 & 0.007 & 0.006 & 0.006 & 0.006 & 0.001 & NS & NS & NS \\
\hline $20: 3 n-6$ & 0.101 & 0.094 & 0.078 & 0.084 & 0.085 & 0.066 & 0.006 & $* *$ & $* * *$ & NS \\
\hline $20: 4 n-3$ & 0.026 & 0.024 & 0.021 & 0.021 & 0.023 & 0.018 & 0.002 & * & $*$ & NS \\
\hline $20: 4 n-6$ & 0.118 & 0.110 & 0.090 & 0.113 & 0.096 & 0.070 & 0.006 & * & $* * *$ & NS \\
\hline $20: 5 n-3$ & 0.041 & 0.037 & 0.029 & 0.040 & 0.034 & 0.023 & 0.002 & * & $* * *$ & NS \\
\hline $22: 0$ & 0.063 & 0.054 & 0.048 & 0.048 & 0.048 & 0.042 & 0.004 & * & $*$ & NS \\
\hline $22: 1$ cis -13 & 0.009 & 0.007 & 0.009 & 0.009 & 0.009 & 0.010 & 0.001 & NS & NS & NS \\
\hline $22: 2 n-6$ & 0.007 & 0.006 & 0.008 & 0.007 & 0.008 & 0.009 & 0.000 & NS & * & NS \\
\hline $22: 4 n-3$ & 0.005 & 0.006 & 0.005 & 0.005 & 0.005 & 0.006 & 0.001 & NS & NS & NS \\
\hline $22: 4 n-6$ & 0.014 & 0.013 & 0.011 & 0.013 & 0.011 & 0.008 & 0.001 & * & $* * *$ & NS \\
\hline $22: 5 n-3$ & 0.061 & 0.054 & 0.048 & 0.054 & 0.047 & 0.037 & 0.004 & * & $* * *$ & NS \\
\hline $22: 5 n-6$ & 0.007 & 0.008 & 0.007 & 0.006 & 0.006 & 0.006 & 0.001 & NS & $\mathrm{NS}$ & NS \\
\hline $22: 6 n-3$ & 0.038 & 0.029 & 0.023 & 0.035 & 0.026 & 0.017 & 0.002 & * & $* * *$ & NS \\
\hline $23: 0$ & 0.020 & 0.016 & 0.014 & 0.019 & 0.015 & 0.011 & 0.001 & NS & $* * *$ & NS \\
\hline \multirow{2}{*}{\multicolumn{11}{|c|}{ Summation by source ${ }^{4}$}} \\
\hline & & & & & & & & & & \\
\hline$<\mathrm{C} 16$ & 26.88 & 24.08 & 20.32 & 25.38 & 23.00 & 19.03 & 0.772 & * & $* * *$ & NS \\
\hline $16: 0$ and $16: 1$ & 36.77 & 35.02 & 32.76 & 39.37 & 35.00 & 33.41 & 0.712 & NS & $* * *$ & NS \\
\hline$>\mathrm{C} 16$ & 36.56 & 41.13 & 46.84 & 35.08 & 41.90 & 47.51 & 1.067 & NS & $* * *$ & NS \\
\hline Total saturated FA & 73.14 & 69.16 & 63.48 & 73.87 & 67.11 & 60.46 & 1.025 & NS & $* * *$ & NS \\
\hline Total MUFA $^{5}$ & 23.51 & 26.84 & 32.07 & 23.00 & 28.91 & 34.51 & 0.959 & NS & $* * *$ & NS \\
\hline Total PUFA ${ }^{6}$ & 3.37 & 4.00 & 4.45 & 3.13 & 3.98 & 5.02 & 0.133 & NS & $* * *$ & $* *$ \\
\hline
\end{tabular}

${ }^{1}$ Probability of significant effects of $\mathrm{MN}$, SBO (linear), and their interaction $(\mathrm{MN} \times \mathrm{SBO}$, linear); $* P<$ $0.05 ; * * P<0.01 ; * * P<0.001$.

${ }^{2}$ Sum of 18:2 FA excluding isomers of conjugated linoleic acid.

${ }^{3}$ Total conjugated linoleic acid.

${ }^{4}$ Fatty acids $<\mathrm{C} 16$ originated from de novo synthesis, FA $>$ C16 were preformed FA taken up by the mammary gland, and 16:0 and 16:1 FA came from both do novo and preformed sources.

${ }^{5}$ Monounsaturated FA.

${ }^{6}$ Polyunsaturated FA. 
Table 6. Mean effects of 3 levels of soybean oil (SBO; $0,1.7$, or $3.4 \%$ of DM) and monensin (MN, 0 vs. 22 $\mathrm{g} / \mathrm{kg} \mathrm{DM}$ ) in the diet on milk 18:2 concentration ( $\mathrm{g} / 100 \mathrm{~g}$ of fatty acids)

\begin{tabular}{|c|c|c|c|c|c|c|c|c|c|c|}
\hline \multirow[b]{2}{*}{ Item } & \multicolumn{3}{|c|}{ Control (no MN) } & \multicolumn{3}{|c|}{$\mathrm{MN}(22 \mathrm{~g} / \mathrm{kg}$ of $\mathrm{DM})$} & \multirow[b]{2}{*}{ SEM } & \multicolumn{3}{|c|}{$P$-value ${ }^{1}$} \\
\hline & 0 & 1.7 & 3.4 & 0 & 1.7 & 3.4 & & $\mathrm{MN}$ & SBO & $\mathrm{MN} \times \mathrm{SBO}$ \\
\hline \multicolumn{11}{|l|}{ Nonconjugated } \\
\hline Cis -9, cis -12 & 1.92 & 2.24 & 2.35 & 1.78 & 2.19 & 2.57 & 0.075 & $\mathrm{NS}$ & $* * *$ & $*$ \\
\hline Trans-11, cis-15 & 0.11 & 0.16 & 0.22 & 0.09 & 0.15 & 0.27 & 0.013 & NS & $* * *$ & $*$ \\
\hline \multicolumn{11}{|l|}{ Conjugated } \\
\hline Cis -9, trans -11 & 0.41 & 0.65 & 0.96 & 0.40 & 0.76 & 1.28 & 0.073 & * & $* * *$ & * \\
\hline Trans-9, cis-11 & 0.036 & 0.045 & 0.059 & 0.038 & 0.051 & 0.09 & 0.005 & ** & $* * *$ & $* *$ \\
\hline Trans -10, cis- 12 & 0.006 & 0.009 & 0.016 & 0.007 & 0.013 & 0.037 & 0.003 & $* * *$ & $* * *$ & $* * *$ \\
\hline Trans -11, trans -13 & 0.015 & 0.016 & 0.021 & 0.016 & 0.017 & 0.022 & 0.002 & NS & $* *$ & NS \\
\hline Trans, trans $^{2}$ & 0.021 & 0.030 & 0.038 & 0.019 & 0.029 & 0.042 & 0.002 & NS & $* * *$ & NS \\
\hline
\end{tabular}

${ }^{1}$ Probability of significant effects of MN, SBO (linear), and their interaction ( $\mathrm{MN} \times \mathrm{SBO}$, linear); $* P<$ $0.05 ; * * P<0.01 ; * * * P<0.001$.

${ }^{2}$ Sum of unresolved trans -9 , trans-11, and trans-10, trans -12 .

were infused abomasally with ethanol as a control treatment, $43 \mathrm{~g} / \mathrm{d}$ of trans-10 18:2, or $4.3 \mathrm{~g} / \mathrm{d}$ of trans-10, cis12 CLA. The experiment confirmed the role of the trans10, cis-12 CLA isomer in inducing milk fat depression. However, they demonstrated that trans-10 had no role in milk fat depression, but it was considered an important biological marker of impaired ruminal $\mathrm{BH}$ due to its high incorporation in milk. Nonetheless, the milk trans-10 18:1 concentration reported by Lock et al. (2007) in the trans-10 18:1 infusion ( $1.11 \mathrm{~g} / 100 \mathrm{~g}$ of FA) was lower than the values reported in the current study for the $3.4 \%$ supplemental SBO treatment (1.30 and $2.64 \mathrm{~g} / 100 \mathrm{~g}$ of FA, without and with added MN, respectively; Table 7). In the current study, milk fat percentage had the greatest correlation with trans-10 18:1 [milk fat percentage $(\mathrm{g} / \mathrm{kg})=22.47 \pm 1.27+31.97 \pm 5.11$ $\exp (-1.99 \pm 0.48$ trans $-1018: 1), \mathrm{n}=70, \mathrm{R}^{2}=0.67, P$ $<0.001]$.
Jenkins et al. (2003) studied the interaction between $\mathrm{MN}$ and unsaturated plant oils on trans FA in bacterial cultures grown in continuous fermentors and fed either corn or barley. They reported that the addition of SBO and $\mathrm{MN}$ to the fermentors individually increased total trans $18: 1$ by 100 and $53 \%$, respectively, with the majority of the increase being in a single isomer, trans-10 18:1. Additionally, they found that feeding a combination of MN and SBO had an additive effect on trans-10 18:1 when barley was fed, and no additive effect was measured when corn was fed. Therefore, the additive effect of trans-10 with barley was not attributed to starch level or to continuous culture $\mathrm{pH}$. High starch digestibility has been shown to reduce the rates of lipolysis and BH (Gerson and King, 1985). They concluded that greater starch digestibility could intensify the ability of MN and unsaturated oil to disrupt BH. In the current study, a corn silage and high-moisture corn

Table 7. Mean effects of 3 levels of soybean oil (SBO; $0,1.7$, or $3.4 \%$ of DM) and monensin (MN, 0 vs. 22 $\mathrm{g} / \mathrm{kg}$ of DM) in the diet on milk $18: 1$ concentration ( $\mathrm{g} / 100 \mathrm{~g}$ of fatty acids)

\begin{tabular}{|c|c|c|c|c|c|c|c|c|c|c|}
\hline \multirow[b]{2}{*}{ Item } & \multicolumn{3}{|c|}{ Control (no MN) } & \multicolumn{3}{|c|}{$\mathrm{MN}(22 \mathrm{~g} / \mathrm{kg}$ of $\mathrm{DM})$} & \multirow[b]{2}{*}{ SEM } & \multicolumn{3}{|c|}{$P$-value ${ }^{1}$} \\
\hline & 0 & 1.7 & 3.4 & 0 & 1.7 & 3.4 & & $\mathrm{MN}$ & SBO & $\mathrm{MN} \times \mathrm{SBO}$ \\
\hline Cis -9 & 17.34 & 18.78 & 21.56 & 16.64 & 19.96 & 20.87 & 0.653 & NS & $* * *$ & NS \\
\hline Cis-11 & 0.70 & 0.77 & 0.82 & 0.74 & 0.79 & 0.99 & 0.061 & NS & $* *$ & NS \\
\hline Cis-12 & 0.27 & 0.49 & 0.57 & 0.26 & 0.44 & 0.49 & 0.034 & NS & $* * *$ & NS \\
\hline Cis-13 & 0.055 & 0.073 & 0.078 & 0.051 & 0.072 & 0.091 & 0.007 & NS & $* * *$ & NS \\
\hline Trans -4 & 0.014 & 0.021 & 0.026 & 0.014 & 0.019 & 0.031 & 0.001 & NS & $* * *$ & NS \\
\hline Trans -5 & 0.012 & 0.015 & 0.023 & 0.011 & 0.017 & 0.028 & 0.002 & NS & $* * *$ & NS \\
\hline Trans $-6+7+8$ & 0.21 & 0.31 & 0.43 & 0.20 & 0.33 & 0.59 & 0.031 & * & $* * *$ & $* *$ \\
\hline Trans-9 & 0.25 & 0.35 & 0.46 & 0.24 & 0.38 & 0.59 & 0.024 & $*$ & $* * *$ & ** \\
\hline Trans-10 & 0.41 & 0.59 & 1.30 & 0.45 & 0.78 & 2.64 & 0.249 & * & $* * *$ & * \\
\hline Trans-11 & 0.90 & 1.47 & 2.12 & 0.91 & 1.64 & 2.74 & 0.133 & * & $* * *$ & * \\
\hline Trans-12 & 0.34 & 0.55 & 0.71 & 0.34 & 0.54 & 0.82 & 0.021 & $*$ & $* * *$ & * \\
\hline Trans $-13+14$ & 0.42 & 0.65 & 0.89 & 0.41 & 0.63 & 0.93 & 0.045 & NS & $* * *$ & NS \\
\hline Trans-16+cis-14 & 0.27 & 0.35 & 0.41 & 0.27 & 0.36 & 0.39 & 0.019 & NS & $* * *$ & NS \\
\hline
\end{tabular}

${ }^{1}$ Probability of significant effects of $\mathrm{MN}, \mathrm{SBO}$ (linear), and their interaction $(\mathrm{MN} \times \mathrm{SBO}$, linear); $* P<$ $0.05 ; * * P<0.01 ; * * * P<0.001$. 
based diet was fed (Table 1). Estimated NFC (\% of DM) for experimental diets ranged from 39 to $40 \%$, which is considered typical for high-producing cows in this region of Ontario. Nonetheless, the ration provided sufficient NDF (35 to $36 \%$ ) with sufficient particle size to maintain a healthy rumen. More studies are needed to investigate the interaction effect of $\mathrm{MN}, \mathrm{SBO}$, and grain level (production level) in the diet on milk fat.

The mechanism by which MN depresses milk fat is not well understood. It was suggested that MN interferes with the $\mathrm{BH}$ of long-chain FA. In an in vitro study, Fellner et al. (1997) demonstrated that ionophores disrupt ruminal $\mathrm{BH}$ by depressing the rate of $18: 0$ production and increasing the concentration of MUFA. In the rumen, the $\mathrm{BH}$ of linoleic acid to linoleic acid is performed by gram-positive bacteria, which are sensitive to $\mathrm{MN}$, whereas the reduction of oleic acid to stearic acid is performed by gram-negative bacteria (Harfoot and Hazelwood, 1988). Additionally, Van Nevel and Demeyer (1995) reported that MN inhibited lipolysis and subsequently reduced the formation of free carboxyl groups necessary for the hydrogenation of double bonds. However, the accumulation of 18:1 isomers cannot be explained by the effect of $\mathrm{MN}$ on gram-positive bacteria (Fellner et al., 1997).

In the current study, evidence of ruminal $\mathrm{BH}$ disruption included a reduction in ruminal milk concentration of stearic acid, and an increase in CLA and vaccenic acid. The changes in milk FA profile also suggest a shift in the $\mathrm{BH}$ pathways represented by an increase in the ratio of trans-10 18:1 to total trans $18: 1(P=0.022)$.

Monensin reduced milk fat yield $(\mathrm{kg} / \mathrm{d})$ likely by altering ruminal $\mathrm{BH}$. However, the reduction in de novo synthesized short- and medium-chain FA $(<\mathrm{C} 16)$ including 6:0, 8:0, 10:0, 14:0 iso, 15:0 iso, and 15:0 anteiso suggests an indirect role of MN in reducing fat synthesis.

In conclusion, our results showed that $\mathrm{MN}$ reduced milk fat percentage. However, the extent of this reduction was dependent on the dietary level of SBO. Milk fat depression was associated with impaired ruminal $\mathrm{BH}$, as indicated by an increase in total trans-10 18:1, and was associated with an increase in CLA isomers believed to have a direct role in inhibiting milk fat synthesis, namely trans-10, cis-12 CLA and trans-9, cis11 CLA. However, more research is needed to investigate other dietary factors that may depresses milk fat such as grain level and its interaction with known dietary factors such as unsaturated fat and MN and to examine mechanism(s) involved in milk fat depression.

\section{ACKNOWLEDGMENTS}

The authors would like to thank Laura Wright and the staff of the Elora Dairy Research Centre (University of Guelph, Ontario, Canada), Qian Zhang for technical assistance, and Elanco Animal Health, Division Eli Lilly Canada Inc. (Guelph, Ontario, Canada) for continued support. We would also like to acknowledge the continued support received from the Ontario Ministry of Agriculture and Food and the Natural Sciences and Engineering Research Council of Canada (B.W.M.).

\section{REFERENCES}

AbuGhazaleh, A. A., D. J. Schingoethe, A. R. Hippen, and K. F. Kalscheur. 2004. Conjugated linoleic acid increases in milk when cows fed fish meal and extruded soybeans for an extended period of time. J. Dairy Sci. 87:1758-1766.

AOAC. 1996. Official Methods of Analysis. 16th ed. Association of Official Analytical Chemists, Arlington, VA.

Bauman, D. E., and J. M. Griinari. 2001. Regulation and nutritional manipulation of milk fat: Low-fat milk syndrome. Livest. Prod. Sci. 70:15-29.

Bauman, D. E., and J. M. Griinari. 2003. Nutritional regulation of milk fat synthesis. Annu. Rev. Nutr. 23:203-227.

Baumgard, L. H., B. A. Corl, D. A. Dwyer, A. Sæbø, and D. E. Bauman. 2000. Identification of the conjugated linoleic acid isomer that inhibit milk fat synthesis. Am. J. Physiol. 278:R179-R184.

Bligh, E. G., and W. J. Dyer. 1959. A rapid method of total lipid extraction and purification. Can. J. Biochem. Physiol. 37:911-917.

DePeters, E. J., and J. P. Cant. 1992. Nutritional factors influencing the nitrogen composition in bovine milk: A review. J. Dairy Sci. 75:2043-2070.

deVeth, M. J., J. M. Griinari, A. M. Pfeiffer, and D. E. Bauman. 2004. Effect of CLA on milk fat synthesis in dairy cows: Comparison of inhibition by methyl esters and free fatty acids, and relationships among studies. Lipids 39:365-372.

Duffield, T. F., and R. N. Bagg. 2000. Use of ionophores in lactating dairy cattle: A review. Can. Vet. J. 41:388-394.

Duffield, T., R. Bagg, D. Kelton, P. Dick, and J. Wilson. 2003. A field study of dietary interactions with monensin on milk fat percentage in lactating dairy cattle. J. Dairy Sci. 86:4161-4166.

Duffield, T. F., D. Sandals, K. E. Leslie, K. Lissemore, B. W. McBride, J. H. Lumsden, P. Dick, and R. Bagg. 1999. Effect of preparturn administration of a monensin controlled release capsule on milk production and milk components in early lactation. J. Dairy Sci. 82:272-279.

Dye, B. E., H. E. Amos, and M. A. Froetschel. 1988. Influence of lasalocid on rumen metabolites, milk production, milk composition and digestibility in lactating cows. Nutr. Rep. Int. 38:101115.

Fellner, V., F. D. Sauer, and J. K. G. Kramer. 1997. Effect of nigericin, monensin, and tetronasin on biohydrogenation in continuous flow-through ruminal fermenters. J. Dairy Sci. 80:921-928.

Gerson, T. A., and A. S. D. King. 1985. The effects of dietary starch and fiber on the in vitro rates of lipolysis and hydrogenation by sheep rumen digesta. J. Agric. Sci. 105:27-30.

Green, H. B., J. T. Symanowski, J. R. Wagner, J. I. D. Wilkinson, and D. G. McClary. 1999. Effect of monensin on milk production parameters, feed intake, body weight, body condition, and efficiency of milk production when fed to Holsteins. Bovine Proc. 32:236-237.

Harfoot, C. G., and G. P. Hazelwood. 1998. Lipid metabolism in the rumen. Page 285 in The Rumen Microbial Ecosystem. P. N. Hobson, ed. Elsevier Sci. Publ., London, UK.

Hayes, D. P., D. U. Pfeiffer, and N. B. Williamson. 1996. Effect of intraruminal monensin capsules on reproductive performance and milk production of dairy cows fed pasture. J. Dairy Sci. 79:1000-1008.

Ipharraguerre, I. R., and J. H. Clark. 2003. Usefulness of ionophores for lactating dairy cows: A review. Anim. Feed Sci. Technol. 106:39-57. 
Jenkins, T. C. 1993. Lipid metabolism in the rumen. J. Dairy Sci. 76:3851-3863.

Jenkins, T. C., V. Fellner, and R. K. McGuffey. 2003. Monensin by fat interactions on trans fatty acids in cultures of mixed ruminal microorganisms grown in continuous fermentors fed corn or barley. J. Dairy Sci. 86:324-330.

Johnson, J. C., P. R. Utley, B. G. Mullinix, and A. Merrill. 1988. Effects of adding fat and lasalocid to diets of dairy cows. J. Dairy Sci. 71:2151-2165.

Lean, I. J., M. Curtis, and R. Dyson. 1994. Effects of sodium monensin on reproductive performance of dairy cattle. 1 . Effects on conception rates, calving to conception intervals, calving to heat and milk production in dairy cows. Aust. Vet. J. 71:273-277.

Licitra, G., T. M. Hernandez, and P. J. Van Soest. 1996. Standardization of procedures for nitrogen fractionation of ruminant feeds. Anim. Feed Sci. Technol. 57:347-358.

Lock, A. L., and K. J. Shingfield. 2004. Optimizing milk composition. Pages 107-188 in Dairying-Using Science to Meet Consumers' Needs. Br. Soc. Anim. Sci. Publ. 29. E. Kebreab, J. Mills, and D. E. Beever, ed. Nottingham University Press, Loughborough, UK.

Lock, A. L., C. Tyburczy, D. A. Dwyer, K. J. Harvatine, F. Destaillats, Z. Mouloungui, L. Candy, and D. E. Bauman. 2007. Trans -10 octadecenoic acid does not reduce milk fat synthesis in dairy cows. J. Nutr. 137:71-76.

Loor, J. J., K. Ueda, A. Ferlay, Y. Chilliard, and M. Doreau. 2004. Biohydrogenation, duodenal flow, and intestinal digestibility of trans fatty acids and conjugated linoleic acids in response to dietary forage: Concentrate ratio and linseed oil in dairy cows. J. Dairy Sci. 87:2472-2485.

Mertens, D. R. 2002. Gravimetric determination of amylase-treated neutral detergent fiber in feeds with refluxing in beakers or crucibles: Collaborative study. J. AOAC 85:1217-1240.

NRC. 2001. Nutrient Requirements of Dairy Cattle. 7th rev. ed. National Acad. Press, Washington, DC.

Odongo, N. E., R. Bagg, G. Vessie, P. Dick, M. M. Or-Rashid, S. E. Hook, J. T. Gray, E. Kebreab, J. France, and B. W. McBride. 2007a. Long-term effects of feeding monensin on methane production in lactating dairy cows. J. Dairy Sci. 90:1781-1788.

Odongo, N. E., M. M. Or-Rashid, E. Kebreab, J. France, and B. W. McBride. 2007b. Effect of supplementing myristic acid in dairy cow rations on ruminal methanogenesis and fatty acid profile in milk. J. Dairy Sci. 90:1851-1858.

Perfield, J. W., II, P. Delmonte, A. Lock, M. P. Yurawecz, and D. E. Bauman. 2006. Trans-10, trans-12 conjugated linoleic acid does not affect milk fat yield but reduces $\Delta^{9}$-desaturase index in dairy cows. J. Dairy Sci. 89:2559-2566.

Perfield, J. W., II, A. L. Lock, J. M. Griinari, A. Sæbø, P. Delmonte, D. A. Dwyer, and D. E. Bauman. 2007. Trans-9, cis-11 conjugated linoleic acid reduces milk fat synthesis in lactating dairy cows. J. Dairy Sci. 90:2211-2218.

Phipps, R. H., J. I. D. Wilkinson, L. J. Jonkert, M. Tarrant, A. K. Jones, and A. Hodge. 2000. Effect of monensin on milk production of Holstein-Friesian dairy cows. J. Dairy Sci. 83:2789-2794.

Precht, D., and J. Molkentin. 1997. Trans-geometric and positional isomers of linoleic acid including conjugated linoleic acid (CLA) in German milk and vegetables fats. Lipids 99:319-326.

Ramanzin, M., L. Bailoni, S. Schiavoni, and G. Bittante. 1997. Effect of monensin on milk production and efficiency of dairy cows fed two diets differing in forage to concentrate ratios. J. Dairy Sci. 80:1136-1142.

Russell, J. B. 2002. Rumen Microbiology and its Role in Ruminant Nutrition. James B. Russell, Ithaca, NY.

Sæbø, A., P. C. Sæbø, J. M. Griinari, and K. J. Shingfield. 2005. Effect of abomasal infusions of geometric isomers of 10, 12 conjugated linoleic acid on milk fat synthesis in dairy cows. Lipids 40:823-832.

SAS Institute. 2004. SAS/STAT Users' Guide, release 9.1. SAS Inst., Inc., Cary, NC.

Sauer, F. D., J. K. G. Kramer, and W. J. Cantwell. 1989. Antiketogenic effects of monensin in early lactation. J. Dairy Sci. 72:436-442.

Shingfield, K. J., S. Ahvenjarvi, V. Toivonen, A. Ärölä, K. V. V. Nurmela, P. Huhtanen, and J. M. Griinari. 2003. Effect of fish oil on biohydrogenation of fatty acids and milk fatty acid content in cows. Anim. Sci. 77:165-179.

Shingfield, K. J., C. K. Reynolds, G. Hervas, J. M. Griinari, A. S. Grandison, and D. E. Beever. 2006. Examination of the persistency of milk fatty acid composition response to fish oil and sunflower oil in the diet of dairy cows. J. Dairy Sci. 89:714-732.

Symanowski, J. T., H. B. Green, J. R. Wagner, J. I. D. Wilkinson, J. S. Davis, M. R. Hirsmstedt, M. S. Allen, E. Block, J. J. Brennan, H. H. Head, J. J. Kennelly, J. N. Nielsen, J. E. Nocek, J. J. Van Der List, and L. W. Whitlow. 1999. Milk production and efficiency of cows fed monensin. J. Dairy Sci. 82(Suppl. 1):171. (Abstr.)

Ulberth, F., and M. Henninger. 1994. Quantitation of trans fatty acids in milk fat using spectroscopic and chromatographic methods. J. Dairy Res. 61:517-527.

van der Werf, J. H. J., L. J. Jonker, and J. K. Oldenbroek. 1998. Effect of monensin on milk production by Holstein and Jersey cows. J. Dairy Sci. 81:427-433.

Van Nevel, C. J., and D. I. Demeyer. 1995. Lipolysis and biohydrogenation of soybean oil in the rumen in vitro: Inhibition by antimicrobials. J. Dairy Sci. 78:2797-2806.

Whitlock, L. A., D. J. Schingoethe, A. R. Hippen, K. F. Kalscheur, T. J. Baer, N. Ramaswamy, and K. M. Kasperson. 2002. Fish oil and extruded soybeans fed in combination increase conjugated linoleic acids in milk of dairy cows more than when fed separately. J. Dairy Sci. 85:556-565. 